\title{
The Inclusion of Intellectual Capital into the Green Board Committee to Enhance Firm Performance
}

\author{
Syed Quaid Ali Shah ${ }^{1}$ (D), Fong-Woon Lai ${ }^{1}$, Muhammad Kashif Shad ${ }^{1}{ }^{(\mathbb{D}}$, Zdeňka Konečná ${ }^{2}$, Feybi Ariani Goni ${ }^{2}$, \\ Abdoulmohammad Gholamzadeh Chofreh ${ }^{3, *(D)}$ and Jiří Jaromír Klemeš ${ }^{3}$ (D)
}

1 Department of Management and Humanities, Universiti Teknologi PETRONAS, Seri Iskandar 32610, Malaysia; syedquaidalishah@gmail.com (S.Q.A.S.); laifongwoon@utp.edu.my (F.-W.L.); mkashifshad@gmail.com (M.K.S.)

2 Department of Management, Faculty of Business and Management, Brno University of Technology-VUT Brno, 61200 Brno, Czech Republic; konecna@fbm.vutbr.cz (Z.K.); goni@vutbr.cz (F.A.G.)

3 Sustainable Process Integration Laboratory-SPIL, NETME Centre, Faculty of Mechanical Engineering, Brno University of Technology_VUT Brno, 61669 Brno, Czech Republic; jiri.klemes@vutbr.cz

* Correspondence: chofreh@fme.vutbr.cz

\section{check for} updates

Citation: Shah, S.Q.A.; Lai, F.-W.; Shad, M.K.; Konečná, Z.; Goni, F.A. Chofreh, A.G.; Klemeš, J.J. The Inclusion of Intellectual Capital into the Green Board Committee to Enhance Firm Performance. Sustainability 2021, 13, 10849. https://doi.org/10.3390/su131910849

Academic Editors

Jennifer Martínez-Ferrero and Giuliana Birindelli

Received: 20 July 2021

Accepted: 21 September 2021

Published: 29 September 2021

Publisher's Note: MDPI stays neutral with regard to jurisdictional claims in published maps and institutional affiliations.

Copyright: (C) 2021 by the authors. Licensee MDPI, Basel, Switzerland. This article is an open access article distributed under the terms and conditions of the Creative Commons Attribution (CC BY) license (https:// creativecommons.org/licenses/by/ $4.0 /)$.

\begin{abstract}
The purpose of this study was to conceptualise a framework that reflects an intertwined relationship between the green board committee and firm performance. Agency and stakeholder theories hold a basic notion of supporting the relationship between the green board committee and firm performance. The moderating role of intellectual capital (IC) was introduced in the intertwined relationship between green board committees and firm performance based on a resource-based view theory. This study proposes a new measurement index, namely, the "green board committee index", to measure the green practices of organisations. This index is comprised of four dimensions: strategy and policymaking, monitoring and control, sustainability, and risk management. The current study hypothesised a significant and positive relationship between the green board committee and firm performance. It was believed that the moderation effect of IC strengthens the relationship between the green board committee and firm performance. The data for this study were proposed to be measured through a content analysis of the company's annual and embedded reports and a Thomson Reuters DataStream terminal. It adds to the body of knowledge by alluding to an integrated notion of green board committees and IC concerning firm performance. The mentioned conceptual framework sends signals to legislators, regulators, policymakers, and practitioners on the critical insights and actions of green board committees in setting strategies and objectives, addressing sustainability issues, forging a relationship with stakeholders, and increasing the firm's value from the business operations.
\end{abstract}

Keywords: green governance; green board committee; stakeholder theory; sustainability; intellectual capital; shareholder value-added

\section{Introduction}

Increasing environmental and social issues have recently attracted huge and in-depth attention from investors and stakeholders around the globe due to rising sustainability issues [1]. The growing environmental and societal challenges have seriously threatened the sustainable development of firms. Stakeholder pressure organisations have been formed to realise the importance of society and the environment [2]. In response to sustainability issues, companies must adopt green practices to improve their sustainability performance in the leadership of sub-board committees [3]. A company's efforts in obtaining sustainability should be conveyed to stakeholders, shareholders, employees, consumers, and public authorities [4].

The corporate board produces board-level committees to strengthen the governance and improve the efficacy of board monitoring [5]. Such committees assist the Board of Directors (BOD) by dividing the board's fiduciary responsibilities. Harrison (1987) argued 
that forming committees in the board room is essential to protect the interest of stakeholders and shareholders [6]. To achieve sustainability, organisations will require a sub-board committee to investigate problems affecting environmental, societal, and financial performance. The corporate board can establish a green board committee that focuses on sustainability performance [7]. Such committees in the board room send signals to stakeholders that organisations are curious to protect them [8]. These committees are becoming a cornerstone in corporate governance mechanisms as they enhance stakeholders' / shareholders' long-term value [9]. The duties and practices that come in the domain of the green board committees are vast, from proposing and implementing strategic sustainability policies to fostering relations with the stakeholders [10].

Previous studies on corporate governance regarding board attributes [3], board characteristics [11], and board compensation [12] have been documented. However, the green board committee in the corporate governance mechanism has drawn little attention among researchers [8]. Prior studies have investigated the effect of green board committees on environmental-social performance [13] and corporate social responsibility (CSR) practices [4]. However, they have neglected its impact on the firm financial performance [13], and the role of the green board committees in the financial performance remains an underresearched subject. From an industrial point of view, it has been observed that the top 100 firms in Malaysia have 24 types of board committees, but a green board committee that focuses on sustainability matters is not available among those firms [14]. It is believed that $65 \%$ of the Standard and Poor (S\&P) 100 firms have green board committees, and they are the main pillar of firms' value and long-term survival [10]. The absence of a green board committee in Malaysian companies raises concerns on how they address these issues of economic, social, and environmental sustainability. This provides an opportunity to present a conceptual framework that shows an intertwined relationship between the green board committee and the firm financial performance.

Effective corporate governance improves firm value through advanced policies, approaches, strategies, and a broad vision. However, in the contemporary world, firm value cannot be promised by the functions of corporate governance, particularly the green board committee. It requires unprecedented efforts and contributions from the top management to the lower-level employees of the firm. In the debate regarding the green board committee and firm performance, it is essential to identify whether other elements could accelerate its nexus. Other factors might affect the connection between green board committees and firm performance. The current study introduces a novel idea of theorising intellectual capital (IC) as a moderator on the relationship between green board committees and firm performance. IC is an organisational asset that is entirely or, to some extent, under the control of the company to support the firm value creation [15]. IC provides a competitive advantage and assists organisations in value creation [16]. It has three main components: human capital, structural capital, and relational capital [17]. Its components drive a firm towards sustainability because it aids the social, environmental, and financial performance of the firm [18]. To the best of our knowledge, no study has used IC as a moderator on the nexus between green board committees and firm performance.

The present study proposes a conceptual framework for all types of companies, particularly for oil and gas companies. Due to its exposure to multiple risks, it is considered the riskiest industry in the world economy [19]. The risks in this industry are not constrained to specific financial or economic characteristics but a myriad of risks encompassing social and environmental aspects. It is worth mentioning that the famous Deepwater Horizon oil spill in 2010 has led to social, environmental, and economic losses due to insufficient attention of corporate governance towards the three dimensions of sustainability [20]. These losses could have been minimal in the presence of specific green board committees. Therefore, the formation of a green board committee could be vital for oil and gas companies.

The objective of the current study is threefold. First, it conceptualises how green board committees contribute to the firm financial performance. Most studies have alluded to the pivotal role of such committees in social and environmental performances but have 
missed its influence on financial performance, and the first objective was to conceptualise the impact of green board committees on financial performance. Second, the literature shows the possibilities of other factors, which, when integrated with the green board committee, can result in higher financial performance. It assumes the role of IC that can strengthen the financial position if integrated with green board committees. Therefore, the second objective reflects the moderating role of IC on the relationship between green board committees and firm performance. Third, previous studies have shown the measurement of the green board committee as a binary variable. An index is presented in the current study. It is comprised of practices that the green board committee performs. The detail of the practices is explained in Section 4: Measurement of Variables. Thus, the third objective is to propose a measuring toolkit for the green board committee.

The current study enriches the corporate governance literature by elaborating the importance of green board committees and their role in enhancing organisational performance. It contributes by introducing IC as a moderator between the green board committee and firm performance. A new index is proposed for measuring the green board committee instead of taking it as a binary variable, as shown in the prior literature. The current study may provide legislators and regulators with critical insights and actions regarding the green board committee in the establishment of corporate strategies and objectives.

The structure of the article is split into several sections. Section 1 explains the stateof-the-art study and research objectives. Section 2 presents a detailed literature review, a theoretical framework, the development of propositions, and a conceptual framework. Section 3 presents the methodology. Section 4 explains the measurement of variables. Section 5 presents the discussion. Section 6 concludes the study with contributions, policy implications, limitations, and recommendations.

\section{Literature Review}

This section sheds light on green board committees and IC and deliberates it with firm performance. The theoretical underpinning, the conceptual framework, and the propositions developed are also carried out in this section.

\subsection{Green Board Committees}

Below is the review of past studies on green board committees, as shown in Table 1. It has been observed that green board committees, committed to economic, social, and environmental matters, are presented with different names, i.e., the environmental committee [21], CSR committee [22], green teams [23], sustainability committee [24], and the sustainability-themed committee [25]. Despite having different names, its purpose is to enhance firm value [9] and manage sustainability-related issues is the same [13]. The documented literature elucidates three dimensions of green governance, i.e., social, environmental, and economic [26]. These three dimensions are dealt with by a specific board committee. Hence, the term "green" regarding such a board committee is used, and it is described as a "green board committee." 
Table 1. Review of prior research studies.

\begin{tabular}{|c|c|c|c|c|c|c|}
\hline Reference & Indexing & $\begin{array}{l}\text { Governance } \\
\text { Variable }\end{array}$ & $\begin{array}{l}\text { Dependent } \\
\text { Variable }\end{array}$ & $\begin{array}{l}\text { Theory } \\
\text { Applied }\end{array}$ & Results Summary & Finding \\
\hline [27] & Scopus & $\begin{array}{l}\text { Environmental } \\
\text { responsibility } \\
\text { committee }\end{array}$ & $\begin{array}{l}\text { Environmental } \\
\text { reporting }\end{array}$ & Agency theory & $\begin{array}{l}\text { Firms with the } \\
\text { environmental committee } \\
\text { present a more } \\
\text { credible disclosure. }\end{array}$ & Positive \\
\hline [28] & $\begin{array}{l}\text { Web of } \\
\text { Science }\end{array}$ & $\begin{array}{l}\text { Environmental } \\
\text { committee }\end{array}$ & $\begin{array}{l}\text { Environmental } \\
\text { strengths and } \\
\text { concerns }\end{array}$ & $\begin{array}{l}\text { Agency and } \\
\text { stakeholder } \\
\text { theory }\end{array}$ & $\begin{array}{l}\text { Such a committee increases } \\
\text { environmental strengths } \\
\text { and mitigates } \\
\text { environmental problems. }\end{array}$ & Positive \\
\hline [29] & $\begin{array}{l}\text { Web of } \\
\text { Science }\end{array}$ & $\begin{array}{l}\text { Socially } \\
\text { responsible } \\
\text { committee }\end{array}$ & $\begin{array}{l}\text { Sustainability } \\
\text { disclosure }\end{array}$ & $\begin{array}{l}\text { Stakeholder } \\
\text { theory }\end{array}$ & $\begin{array}{l}\text { The existence of a } \\
\text { sustainability committee } \\
\text { does not improve overall } \\
\text { sustainability disclosure. }\end{array}$ & $\begin{array}{c}\text { Positive } \\
\text { insignificant }\end{array}$ \\
\hline [30] & $\begin{array}{l}\text { Web of } \\
\text { Science }\end{array}$ & CSR committee & $\begin{array}{l}\text { Environmental } \\
\text { performance }\end{array}$ & $\begin{array}{l}\text { Legitimacy } \\
\text { theory }\end{array}$ & $\begin{array}{l}\text { Insignificant association } \\
\text { between CSR committee and } \\
\text { environmental disclosure. }\end{array}$ & $\begin{array}{c}\text { Negative } \\
\text { insignificant }\end{array}$ \\
\hline$[31]$ & $\begin{array}{l}\text { Web of } \\
\text { Science }\end{array}$ & $\begin{array}{l}\text { Environmental } \\
\text { committee }\end{array}$ & $\begin{array}{l}\text { Green } \\
\text { performance }\end{array}$ & $\begin{array}{l}\text { Stakeholder } \\
\text { and legitimacy } \\
\text { theory }\end{array}$ & $\begin{array}{l}\text { The environmental } \\
\text { committee, as a symbolic } \\
\text { approach, only manages } \\
\text { stakeholder perceptions. }\end{array}$ & $\begin{array}{c}\text { Negative } \\
\text { insignificant }\end{array}$ \\
\hline [23] & $\begin{array}{l}\text { Web of } \\
\text { Science }\end{array}$ & Green teams & $\begin{array}{l}\text { Environmental } \\
\text { performance } \\
\text { and reputation }\end{array}$ & - & $\begin{array}{l}\text { Green teams significantly } \\
\text { improve firm environmental } \\
\text { performance and reputation }\end{array}$ & Positive \\
\hline [3] & Scopus & $\begin{array}{l}\text { Environmental } \\
\text { committee }\end{array}$ & $\begin{array}{l}\text { Carbon } \\
\text { disclosure }\end{array}$ & $\begin{array}{l}\text { Legitimacy and } \\
\text { stakeholder } \\
\text { theory }\end{array}$ & $\begin{array}{l}\text { Significant nexus between } \\
\text { the committee and } \\
\text { carbon disclosure. }\end{array}$ & Positive \\
\hline [32] & $\begin{array}{l}\text { Web of } \\
\text { Science }\end{array}$ & CSR committee & $\begin{array}{c}\text { CSR } \\
\text { performance }\end{array}$ & $\begin{array}{l}\text { Institutional } \\
\text { theory }\end{array}$ & $\begin{array}{l}\text { Such a committee is an } \\
\text { influencer of } \\
\text { CSR performance }\end{array}$ & positive \\
\hline [25] & $\begin{array}{l}\text { Web of } \\
\text { Science }\end{array}$ & $\begin{array}{l}\text { Sustainability- } \\
\text { themed } \\
\text { committee }\end{array}$ & $\begin{array}{l}\text { Green and } \\
\text { financial } \\
\text { performance }\end{array}$ & $\begin{array}{l}\text { Stakeholder } \\
\text { theory }\end{array}$ & $\begin{array}{l}\text { The committee reflects } \\
\text { negative nexus with green } \\
\text { performance, but green } \\
\text { performance assists in } \\
\text { financial performance }\end{array}$ & Negative \\
\hline [13] & $\begin{array}{l}\text { Web of } \\
\text { Science }\end{array}$ & $\begin{array}{l}\text { Sustainability } \\
\text { committee }\end{array}$ & $\begin{array}{l}\text { Social and } \\
\text { environmental } \\
\text { performance }\end{array}$ & $\begin{array}{l}\text { Stakeholder } \\
\text { theory }\end{array}$ & $\begin{array}{l}\text { This committee improves } \\
\text { non-financial performance }\end{array}$ & Positive \\
\hline [22] & $\begin{array}{l}\text { Web of } \\
\text { Science }\end{array}$ & $\begin{array}{l}\text { Sustainability- } \\
\text { themed } \\
\text { committee }\end{array}$ & $\begin{array}{c}\text { Green } \\
\text { performance }\end{array}$ & $\begin{array}{l}\text { Stakeholder } \\
\text { theory }\end{array}$ & $\begin{array}{l}\text { The adoption of a } \\
\text { sustainability-themed } \\
\text { committee significantly } \\
\text { improves green performance }\end{array}$ & Positive \\
\hline [33] & $\begin{array}{l}\text { Web of } \\
\text { Science }\end{array}$ & CSR committee & $\begin{array}{l}\text { Sustainability } \\
\text { performance }\end{array}$ & $\begin{array}{l}\text { Agency and } \\
\text { stakeholder } \\
\text { theory }\end{array}$ & $\begin{array}{l}\text { The presence of a CSR } \\
\text { committee positively } \\
\text { influences environmental } \\
\text { and social performance. }\end{array}$ & Positive \\
\hline [34] & $\begin{array}{l}\text { Web of } \\
\text { Science }\end{array}$ & CSR committee & $\begin{array}{l}\text { Economic, } \\
\text { social, and } \\
\text { environmental } \\
\text { performance }\end{array}$ & $\begin{array}{l}\text { Stakeholder } \\
\text { theory }\end{array}$ & $\begin{array}{l}\text { CSR committee brings } \\
\text { significant enhancement in } \\
\text { economic, social, and } \\
\text { environmental performance }\end{array}$ & Positive \\
\hline [35] & $\begin{array}{l}\text { Web of } \\
\text { Science }\end{array}$ & CSR committee & $\begin{array}{l}\text { Sustainability } \\
\text { disclosure }\end{array}$ & $\begin{array}{l}\text { Agency and } \\
\text { stakeholder } \\
\text { theory }\end{array}$ & $\begin{array}{l}\text { Shows significant association } \\
\text { between CSR committee and } \\
\text { sustainability disclosure. }\end{array}$ & Positive \\
\hline
\end{tabular}


Table 1. Cont.

\begin{tabular}{|c|c|c|c|c|c|c|}
\hline Reference & Indexing & $\begin{array}{l}\text { Governance } \\
\text { Variable }\end{array}$ & $\begin{array}{l}\text { Dependent } \\
\text { Variable }\end{array}$ & $\begin{array}{l}\text { Theory } \\
\text { Applied }\end{array}$ & Results Summary & Finding \\
\hline$[21]$ & $\begin{array}{l}\text { Web of } \\
\text { Science }\end{array}$ & $\begin{array}{l}\text { Environmental } \\
\text { committee }\end{array}$ & $\begin{array}{l}\text { Environmental } \\
\text { quality }\end{array}$ & $\begin{array}{l}\text { Stakeholder } \\
\text { and resource } \\
\text { dependency } \\
\text { theory }\end{array}$ & $\begin{array}{l}\text { Insignificant association } \\
\text { between the environmental } \\
\text { committee and quality. }\end{array}$ & Negative \\
\hline [10] & $\begin{array}{l}\text { Web of } \\
\text { Science }\end{array}$ & $\begin{array}{l}\text { Sustainability } \\
\text { committee }\end{array}$ & $\begin{array}{l}\text { Corporate } \\
\text { social } \\
\text { performance } \\
\text { (CSP) }\end{array}$ & $\begin{array}{l}\text { Accountability } \\
\text { theory }\end{array}$ & $\begin{array}{l}\text { The effect of sustainability is } \\
\text { economically significant. }\end{array}$ & Positive \\
\hline [7] & $\begin{array}{l}\text { Web of } \\
\text { Science }\end{array}$ & CSR committee & $\begin{array}{c}\text { GRI-IFC } \\
\text { performance }\end{array}$ & $\begin{array}{l}\text { Agency- } \\
\text { stakeholder } \\
\text { theory }\end{array}$ & $\begin{array}{l}\text { Significant positive nexus } \\
\text { between CSR committee and } \\
\text { GRI-IFC performance. }\end{array}$ & Positive \\
\hline [9] & $\begin{array}{l}\text { Web of } \\
\text { Science }\end{array}$ & CSR committee & $\begin{array}{l}\text { Non-financial } \\
\text { disclosure }\end{array}$ & $\begin{array}{l}\text { Institutional } \\
\text { theory }\end{array}$ & $\begin{array}{l}\text { CSR committee has an } \\
\text { impact on } \\
\text { non-financial disclosure. }\end{array}$ & Negative \\
\hline [36] & $\begin{array}{l}\text { Web of } \\
\text { Science }\end{array}$ & CSR committee & $\begin{array}{l}\text { Sustainability } \\
\text { performance }\end{array}$ & - & $\begin{array}{c}\text { Significant positive } \\
\text { association of CSR } \\
\text { committee with social and } \\
\text { environmental performances. }\end{array}$ & Positive \\
\hline [37] & $\begin{array}{l}\text { Web of } \\
\text { Science }\end{array}$ & $\begin{array}{l}\text { Sustainability } \\
\text { committee }\end{array}$ & $\begin{array}{c}\text { Financial } \\
\text { performance }\end{array}$ & Agency theory & $\begin{array}{c}\text { Significant nexus between } \\
\text { sustainability and } \\
\text { financial performance. }\end{array}$ & Positive \\
\hline [38] & $\begin{array}{l}\text { Web of } \\
\text { Science }\end{array}$ & $\begin{array}{l}\text { Sustainability } \\
\text { committee }\end{array}$ & $\begin{array}{l}\text { Social } \\
\text { performance, } \\
\text { environmental } \\
\text { performance }\end{array}$ & $\begin{array}{l}\text { Stakeholder } \\
\text { and upper } \\
\text { echelons } \\
\text { theories }\end{array}$ & $\begin{array}{c}\text { Positive association of } \\
\text { sustainability committees } \\
\text { with social and } \\
\text { environmental performance. }\end{array}$ & Positive \\
\hline [39] & $\begin{array}{l}\text { Web of } \\
\text { Science }\end{array}$ & CSR committee & $\begin{array}{c}\text { ESG } \\
\text { performance }\end{array}$ & $\begin{array}{l}\text { Agency and } \\
\text { stakeholder } \\
\text { theory }\end{array}$ & $\begin{array}{l}\text { CSR committee has a } \\
\text { positive effect on } \\
\text { ESG performance. }\end{array}$ & Positive \\
\hline [24] & $\begin{array}{l}\text { Web of } \\
\text { Science }\end{array}$ & CSR committee & $\begin{array}{c}\text { ESG } \\
\text { performance }\end{array}$ & $\begin{array}{l}\text { Resource } \\
\text { dependency } \\
\text { theory }\end{array}$ & $\begin{array}{l}\text { Positive nexus between CSR } \\
\text { committee and } \\
\text { ESG performance. }\end{array}$ & Positive \\
\hline [40] & $\begin{array}{l}\text { Web of } \\
\text { Science }\end{array}$ & CSR committee & $\begin{array}{c}\text { CSR } \\
\text { performance }\end{array}$ & $\begin{array}{l}\text { Stakeholder- } \\
\text { agency } \\
\text { theory }\end{array}$ & $\begin{array}{l}\text { CSR committee improves } \\
\text { CSR performance. }\end{array}$ & Positive \\
\hline$[4]$ & $\begin{array}{l}\text { Web of } \\
\text { Science }\end{array}$ & $\begin{array}{l}\text { Sustainability } \\
\text { committee }\end{array}$ & CSR reporting & $\begin{array}{l}\text { Stakeholder } \\
\text { and resource } \\
\text { dependency } \\
\text { theory }\end{array}$ & $\begin{array}{l}\text { Significant nexus between } \\
\text { sustainability committee and } \\
\text { CSR reporting. }\end{array}$ & Positive \\
\hline
\end{tabular}

There has been a surge in the existence of green board committees in organisations, as elucidated by prior studies. Spitzeck analysed the data of 51 UK firms and indicated the presence of green board committees within the boards of surveyed firms. Another study reported the existence of such committees in highly sustainable companies by exploring 675 US firms [41]. Adel et al. [35] expanded on the existence of green board committees in the S\&P Europe 350 companies. Burke et al. [10] revealed the rising trend of green board committees in listed public firms. Gennari and Salvioni [9] highlighted a spike in the establishment of green board committees from $2.46 \%$ to $6.70 \%$ spanning 2000-2016. Practitioners like Calvert Asset Management and the Corporate Library [42] and the Institute of Business Ethics [43] also evidenced the increasing presence of such committees. This kind of rising momentum underlines the essence of green board committees in organisations to achieve sustainability. 
The mandate of green board committees in the board room is connected to firm sustainability and is not limited to ecological issues [25]. The onus of economic and social matters also comes under the domain of these committees, and organisations are forming green board committees to utilise their vital skills in sustainability responsibilities. Such committees support the directors on the board in monitoring and reviewing the sustainability performance by ensuring companies' adherence to corporate codes that overcome sustainability risks [34]. Green committees design CSR strategies, meet stakeholder's demands and improve the firm's reputation [44]. The existence of such specific committees increases the creditability of environmental and social disclosure [27].

Various researchers lay stress upon creating green board committees as a fundamental governance mechanism for companies to increase opportunities for sustainable development. In a related study, Rodrigue et al. [31] described the function of green board committees in the following way: "the committee makes sure to tell the board: here it is, we conducted a diligent review, everything is under control, except here, except there, and we will follow up". Liao et al. [3] added: "the role of an environmental committee with respect to environmental disclosure is analogous to the role of an audit committee in ensuring proper financial accounting disclosures". Biswas et al. [13] quoted from Rio Tinto's website: "the sustainability committee assists the board with overseeing strategies designed to manage social and environmental risks, overseeing management processes and standards and achieving compliance with social and environmental responsibilities and commitments". Hussain et al. [33] stated that "the existence of a CSR committee symbolises the board's orientation and commitment towards sustainable development". In a nutshell, a firm having a green board committee is committed to CSR and stakeholder's demand, but it also consistently plays an advisory role to enhance sustainability performance to make sustainability a fundamental core strategy. In this vein, academicians attempt to explore the effect of green board committees on firm performance.

Walls et al. [28] demonstrated that green board committees increase environmental quality and reduce its hazards. Dangelico [23] explored a significant improvement in the ecological performance and reputation of the firms with green committees. In the same fashion, Lio et al. [3] showed that green board committees significantly contribute to the transparency of carbon disclosure. An empirical study by Vigneau et al. [32] to identify the nexus between green board committees and CSR performance in North America and Europe validated the link of CSR performance to green board committees. In contrast, Li et al. [25] revealed no enhanced financial performance directly but assisted in accounting performance through green performance. Biswas et al. [13] empirically tested the effect of green board committees on social and ecological performance in Australian firms and revealed a direct relation in such indicators.

Chen et al. [22] reported a significant association between green committees and green performance. An increase in firm performance and GBC was also complemented by the reference [33] and [34], which investigated a nexus between green committees and sustainability performance and found that the presence of green board committees had the strongest influence on the economic, social, and environmental dimensions of sustainability. In the UK, Adel et al. [35] revealed that the firms in the UK with green board committees significantly impact the quality of non-financial reporting. Equally, Burke et al. [10] signified the positive relationship between green board committees and corporate sustainability performance. On the contrary, Gennari and Salvioni [9] indicated a statistically significant nexus amid green committees and non-financial disclosure but in a negative direction. Employing the GMM econometric technique, Cancela et al. [36] observed a substantial positive effect of green board committees as a governance tool on sustainability performance. Similar findings were evident by [37]. Noja et al. [38], using agency theory, obtained the significant impact of green governance committees on the financial performance of firms. Shahbaz et al. [39] conducted empirical studies to examine the effect of the green board committees on ESG performance and found a significant positive association between the two constructs. Elmaghrabi [40] tested the 
nexus between the green board committee and CSR performance and concluded that the presence of such committees could significantly contribute to a firm's CSR performance. Kilic et al. [4] found an improvement in non-financial reporting with the engagement of green board committees.

Numerous researchers have highlighted the main roles of green boards contributing to firm performance, as shown in Figure 1. However, some researchers critiqued the existence of green board committees due to their insignificant role in the organisation's performance. As mentioned above, Michelon and Parbonetti [29] found an insignificant nexus between green board committees and sustainability disclosure. They further argued that the existence of such committees only improves social disclosure but not overall sustainability disclosure. Rupley et al. [30] explored an insignificant relationship between green board committees and ecological performance. Rodrigue et al. [31] criticised the existence of green board committees after investigating their negative and statistically insignificant effect on performance. They argued that such committees, as a symbolic approach, only manage stakeholder perceptions. During empirical testing of green board committees and the environmental quality of French-listed companies spanning in years 2009-2014, Baalouch et al. [21] found an insignificant relationship. They declared it as a legitimacy tool that does not necessarily contribute to non-financial reporting.

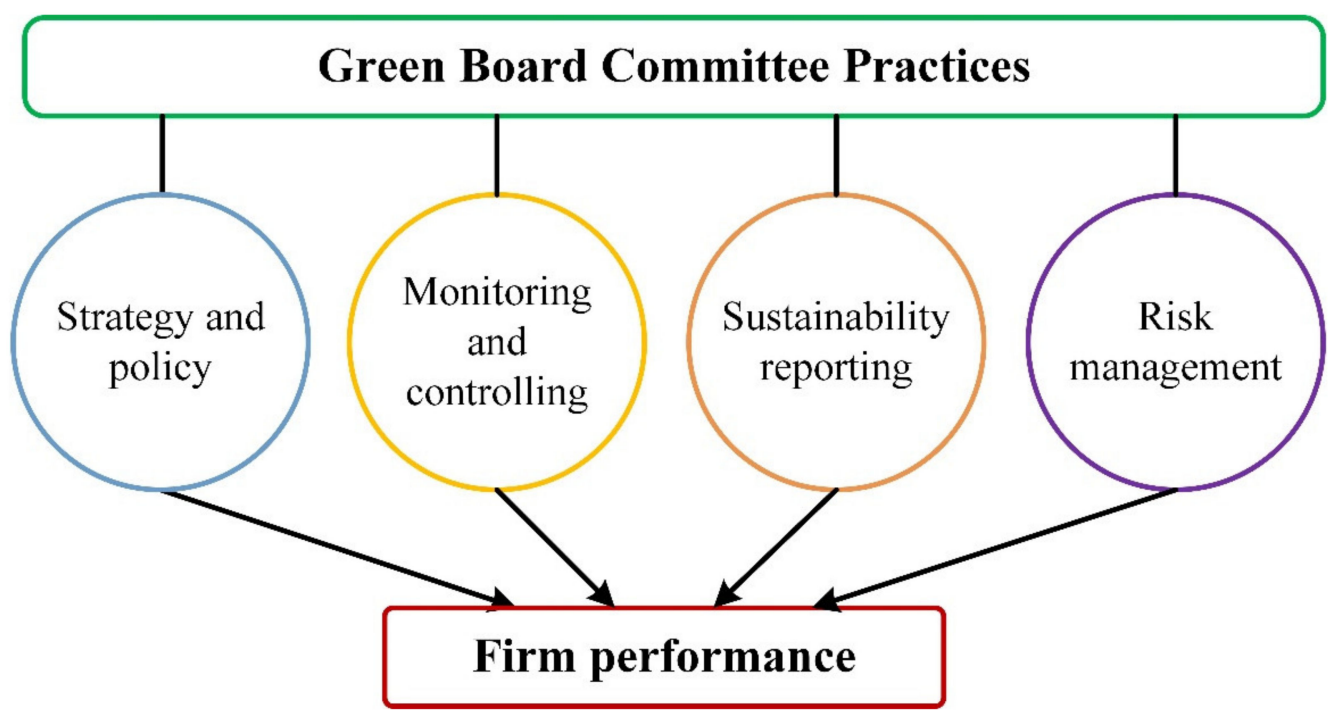

Figure 1. Green board committee roles and firm performance.

\subsection{Firm Performance}

A performance indicator facilitates investors in investment decisions regarding whether to invest or step back from a particular business. Researchers, academicians, and practitioners use the performance indicators as a dependent variable to examine the influence of the predictor variable on it. Organisations use different performance indicators, such as earnings per share, return on assets (ROA), return on equity (ROE), market to book value, Tobin's Q, return on investment, economic value-added and so forth per their strategies and objectives [45]. It is important to highlight the best performance indicator that reflects the value creation information to investors.

Performance measures are classified into objective and subjective measures. Objective measures are computed using secondary data, while subjective measures are quantified using primary data. Objective measures are further categorised into three types. First, the financial performance includes traditional measures like return on assets, equity, return on investment, and operating profit. Second, the market performance, which includes sales and market shares. Third, shareholder return, which includes shareholder value-added and economic value-added. The accounting performance measures are critiqued in academia as they lack the reflection of shareholder value [46]. Studies have identified that financial- 
or accounting-based measures could provide misleading information on the company's progress and innovation [47].

Shad et al. [48] have recommended that corporations should use economic valueadded (EVA) for firm performance. However, Fernandez [49] advocated that EVA and market value do not indicate shareholder return. It is further criticised that EVA does not measure value creation [50]. In the present time of strong competition and globalisation, value and wealth creation for shareholders are more significant. So, the firm should use indicators that can reflect the transmission mechanism to shareholders as to how their value is created. Based on economic theories, shareholder value-added (SVA) has drawn the attention of researchers and industry practitioners highly [51]. Rappaport [52] discovered SVA as a performance indicator in 1986. SVA's prettiness is that it reflects a transmission mechanism to the shareholders about how their value is created. It is defined as the excess income that the firms earn after the deduction of funding costs [51]. It is calculated as follows: Equation (2).

SVA represents shareholder value-added. NOPAT is the operational efficiency of the firm, i.e., net operating profit after tax. The WACC is the weighted average cost of capital that includes the cost of debt and equity. SVA as a performance indicator will show how the management has utilised the company resources to create organisational value. The other performance indicators in relation to the green board committee are depicted in Table 1.

\subsection{Related Theories}

This portion deliberates on the theoretical support for a direct link between green board committees and firm performance. Prior studies argued for the inappropriateness of using a single theory to justify the role of green board committees. Agency and stakeholder theories are utilised to support the intertwined relationship between green board committees and firm performance. Both of the theories complement each other. The study used a resource-based view theory to support the moderation role of IC on the relationship between green board committee and firm performance. The subsequent section presents an explanation of these theories.

\subsubsection{Agency Theory}

Agency theory, proposed by Jensen and Meckling [53], is based on characteristic behaviour and conflicts of interest between management, stakeholders, and shareholders. It asserts that good corporate governance can enhance the ability of companies to cope with rising challenges and plays an essential role in resolving agency conflict [53]. As opportunism is characteristic of human beings, managers can emphasise self-interest-based business operations at the expense of shareholders and stakeholders. For instance, they can adopt a greenwashing approach and could mislead the shareholders and stakeholders in preparing sustainability reports, resulting in information asymmetry and a conflict of interest among stakeholders. In such cases, agency theory mandates forming board-level committees to closely monitor the management activities, reduce information asymmetry, and ensure the business operations' alignment with the interest of stakeholders [33]. The green board committee is vital to oversee the management activities and for the control of sustainability issues. It is pertinent to mention that agency theory favours green board committees that extend the attention of the company to sustainability issues and that mitigate the conflict of interest between management and stakeholders [35]. A vast amount of literature on agencies indicates that a company can enhance its legitimacy [29] and financial performance in the presence of effective board committees such as the green board committee.

\subsubsection{Stakeholder Theory}

Freeman, in 1984, presented stakeholder theory, which advocates that the long-term objectives of an enterprise could be achieved with a strong bond among multiple stakeholders [54]. This theory asserts that shareholders and investors are not the only stakeholders, 
but other groups are within and outside the organisation. Stakeholders have expectations from organisations, which are essential to be met by the organisations. The multiple stakeholders, such as shareholders, managers, creditors, investors, customers, suppliers, employees, government, communities, agencies, and media groups, show an interest in knowing how the company operations influence them [55]. Due to rising conflicts from organisation operations, stakeholders expect organisations to disclose their sustainability reports, which work as a communication channel between companies and the respective stakeholders [56]. The existence of green board committees, which perform a major role in the preparation of sustainability reports, can overcome the concerns of stakeholders via sustainability reporting. They develop a good corporate image that eventually increases the firm performance. Green board committees can also indirectly mitigate the firm's cost through sustainability practices [19]. Stakeholder theory supports the conflict-free stakeholder-management relationship that improves the firm performance [57]. The study contends that the green board committee balances the monetary and non-monetary goals using fewer resources and that it meets the multiple stakeholders' interests [3].

\subsubsection{Resource-Based View Theory}

Penrose laid the foundation of the resource-based view theory (RBV) in the book "The Theory of the Growth of the Firm", which was published in 1959 [58]. However, more attention has been directed towards the paper "Firm Resources and Sustained Competitive Advantage" produced by Jay Barney, who has advanced the concept of RBV theory. The firm long-term survival and competitive advantage are linked with strategic resources that other companies cannot replicate [59]. Integration of resources results in an effective service or product [60]. Inimitable and rare resources provide a sustainable advantage and improve the firm profitability [61]. The IC is also a resource that cannot be replicated by another enterprise. It includes humans as wells as organisational structural capital. The green board committee increases the overall sustainability performance of the firms. If the company enriches green board committees with IC such as education, knowledge, experience, training, skills, organisation processes, databases, and supportive infrastructure, the outcome of the committee may be high. Therefore, IC performs a vital role in a firm's performance at every level [59].

\subsection{Development of Hypothesis}

\subsubsection{Green Board Committees and Firm Performance}

The green board committee is an essential element of the corporate governance mechanism. The top tone of corporations might ignore the sustainability obligations and focus on short-term accounting returns. In such cases, green board committees can influence management to endorse socio-economic policies. As stated above, agency theory asserts that board-level committees oversee and control the actions of management. Thus, green board committees are crucial to monitor overall operations and control emerging issues that might allocate the company resources to accelerate the sustainability practices for better stakeholder management [33]. Green board committees related to social and environmental performance have been documented extensively, but its nexus with financial performance, particularly shareholder value-added, is scant. However, studies are gaining traction (See Table 1). In one study, an increase in environmental and social performance was attributed to green board committees [13]. It is crucial as it mandates implementing CSR activities at the top tone, satisfying stakeholders' demands and improving the firm reputation [62]. Eberhardt-Toth [8] assumed that a firm equipped with a green board committee could attain high corporate social performance. A more recent conceptual study presumed that organisations with green board committees might perhaps enhance the community, environment, product, services, and business ethics, which, in return, earn a good image and reputation [63]. Consequently, a good reputation might result in financial benefits [48]. 
The literature reflects exciting notions on the nexus of a green board committee and firm performance. However, they are limited to non-financial performance, and financial results are yet to be explored. Based on the above discussion and in light of agency and stakeholder theory, the current study hypothesised a direct positive nexus between the green board committee and firm financial performance. Thus, the following hypothesis is postulated.

Hypothesis 1 (H1). Green board committees have a significant positive impact on the financial performance of the firm.

\subsubsection{Moderating Role of Intellectual Capital}

Following the concept of Baron and Kenny [64], moderation is the action of the third variable that compounds the bond between independent and dependent variables. The moderator does not need to be an antecedent to the predictor variable. The intensity of moderating and independent variables is of the same level regarding their role as a causal antecedent to the specific criterion impacts. In this vein, the present study assumed the moderating effect of IC, which may increase the capability and capacity of green board committees that might strengthen the financial sustainability of an organisation.

Our contemporary world is full of uncertainties, and an enterprise could be exposed to many risks [65]. For instance, the recent COVID-19 pandemic has chiefly disturbed almost every industry around the globe [66]. Over the last decade, new technologies have had a significant effect on societies [67]. Such uncertainties could not be reduced only with the corporate governance and the establishment of specific board committees. To survive in unpredictable conditions, firms need to change their strategies from a labour-based to a knowledge-based business along with the possession of intangible resources, i.e., IC, which is generally defined as the mind or human brain's ability that helps the organisation in value creation [68]. It is not displayed on the balance sheet, but it plays a vital role in an organisation's performance.

Organisational sustainability issues are dealt with by green board committees, while the literature reflects on common features between sustainability and IC [69]. Technically, to some extent, green board committees depend on organisational IC to attain high performance. Higher firm performance is assumed if green board committees are enriched with IC, which is a significant element in business that bestows the firm with a competitive advantage [17]. A human capital aspect of IC may increase green board committees' knowledge, creativity, skills, and willpower. In contrast, structural capital provides a foundation for the execution of human capital [70]. Organisations are counselled to invest in IC for two reasons: it enriches organisations economically, i.e., improves their financial performance, and it also promotes mission-based performance [16]. From the above discussion and RBV theory, the following hypothesis is postulated.

Hypothesis 2 (H2). Intellectual capital has a significant positive impact on the relationship between green board committees and firm performance.

\subsection{Conceptual Framework}

Figure 2 presents a conceptual framework of the study. It comprises multiple concepts and contexts to achieve a mechanism that provides the correct and aligned interpretation of the subject at stake [48]. Over the last two decennaries, the launching of millennium development goals (MDGs) and sustainable development goals (SDGs) have increased the importance of green board committees in organisations due to their multipurpose role in protecting society, the environment, and the economy. Despite its high importance, scant literature exists on the inspection of the green board committee and firm performance. In the wake of growing stakeholders' demands and increased sustainability issues, our work produced a conceptual framework of green board committees and firm performance by integrating IC between two variables. Thus, it provides academics and practitioners 
with an essential contribution by having increased firm value through green board committees. It engages in strategy making, monitoring, controlling, sustainability reporting, and management of sustainability risks. The firm value increases when the committee monitors and controls the management actions against the interests of shareholders and stakeholders. Its engagement in sustainability reporting reduces information asymmetry and reducing asymmetry cost, which increases the firm value. In the presence of emerging risks, organisations' performance may deteriorate in the absence of such committees. It helps in identifying and planning mitigation actions against the risks that consequently increase the firm performance. However, there is always a potential for improvement that can be fulfilled by the integration of IC, which assists in the company's growth with minimum resource utilisation. It is essential for economic success and to address the ecological and social problems that societies may face. When organisations invest in IC, it achieves sustainability targets [71]. The authors' opinion is that integrating IC would increase the capacity and capability of the green board committee, resulting in higher firm value. A causal relationship is drawn between green board committees and firm performance in light of agency and stakeholder theories. Specifically, RBV theory is utilised to support the moderating role of IC.

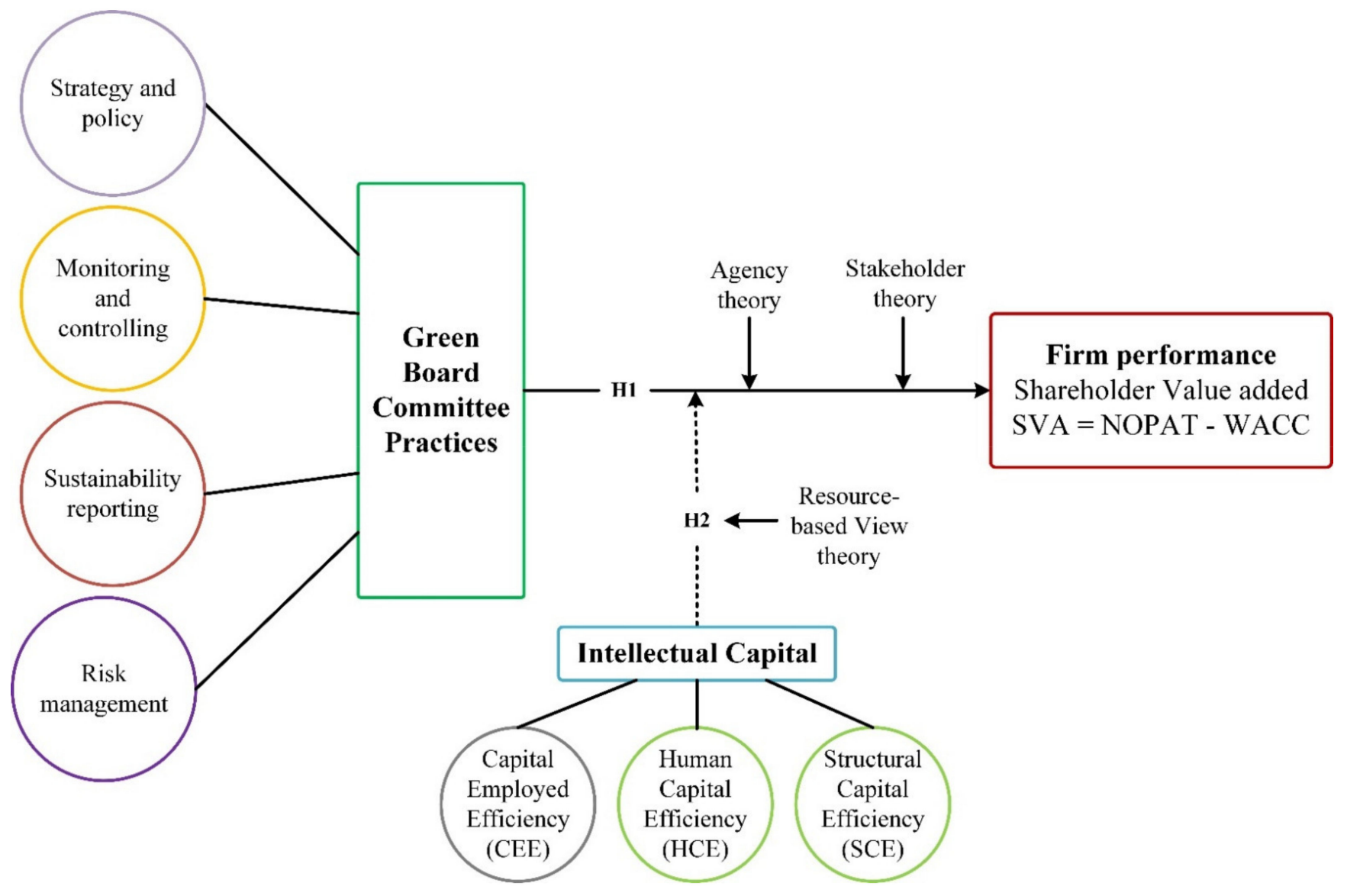

Figure 2. A conceptual framework linking green board committee, intellectual capital, and firm performance.

The framework below is comprised of three types of variables: an explanatory variable, a moderating variable, and a dependent variable. The dependent variable reflects the firm performance proxied by shareholder value-added. The green board committee is used as an explanatory variable, whilst IC is incorporated as a moderating variable. The green board committee is assumed to increase the firm performance by designing strategies and policies, monitoring and controlling, sustainability reporting, and by engaging in risk 
management. It is also suggested that the integration of IC will moderate the positive relationship between the green board committee and firm performance.

\section{Methodology}

The study proposes a conceptual framework by applying a qualitative approach to green board committees' gist and their subsequent impact on firm performance. In this respect, related research studies are compiled in a systematic way. This method is utilised as it connects the literature of a specific area and presents an integrated knowledge to academicians and policymakers by proposing a framework [72].

Two well-known databases, Scopus and Web of Science, are used as recommended by Ali et al. [73]. Both databases are preferred because they are highly recognised for publishing theoretical, conceptual, and empirical articles. The concept was carried out in five steps. Figure 3 depicts an inclusive view of this research document. In step 1, the related databases, i.e., Scopus and Web of Science, are chosen. The main focus is on theoretical, conceptual and empirical studies. A time frame of 2012-2021 is selected. The rationale for searching articles in this particular period is that this research area has rarely been investigated. Debate on this topic is growing due to its contribution to the sustainable development goals issued by the United Nations. A short combination of keywords has been skimmed in the abstracts and body of studies. The following keywords are used: "CSR committee" OR "green board committee" OR "sustainability committee" OR "environmental committee" OR "social sustainability committee." In step 2, the authors are engaged in a careful reading of the abstracts and the findings of the documents. Only those studies are included, reflecting the aim of green board committees and their impact on firm performance. Related concepts and constructs are collected and then classified. In step 3, a conceptual framework is designed, and the links are established between constructs. In the penultimate step, key concepts are conveyed. For the advancement of study, propositions are intended to prove the new concepts.

The study proposes sampling and potential modelling. The sample comprises listed oil and gas companies of Malaysia. The analysis spanned ten years of data because it covers the era before and after the launching of SDGs. The data type is panel data, which is a mixture of both time-series and cross-sectional data. This work proposes a weighted content analysis of annual reports to compute the green board committee index. The reason for suggesting weighted content analysis is its ability to verify more significant information than an unweighted content analysis [74]. Academicians also focus on the usage of content analysis [75]. IC and shareholder value-added are measured using secondary data obtained from annual reports and a Thomson Reuters DataStream terminal.

Given the nature of the data balance panel data, a linear regression model is proposed to examine the impact of green board committees on firm performance under the moderating effect of IC. To avoid econometric issues and for smooth analysis, it is pivotal to address some important diagnostic checks such as data normality, multicollinearity, and endogeneity issues [76]. The Hausman test is recommended to choose the appropriateness of the model between the random and fixed effects. In addition, this work proposed to utilise simultaneous equation models, i.e., two-stage least-squares and system-generalised methods of moments as robust testing to examine the sensitivity of the results. 


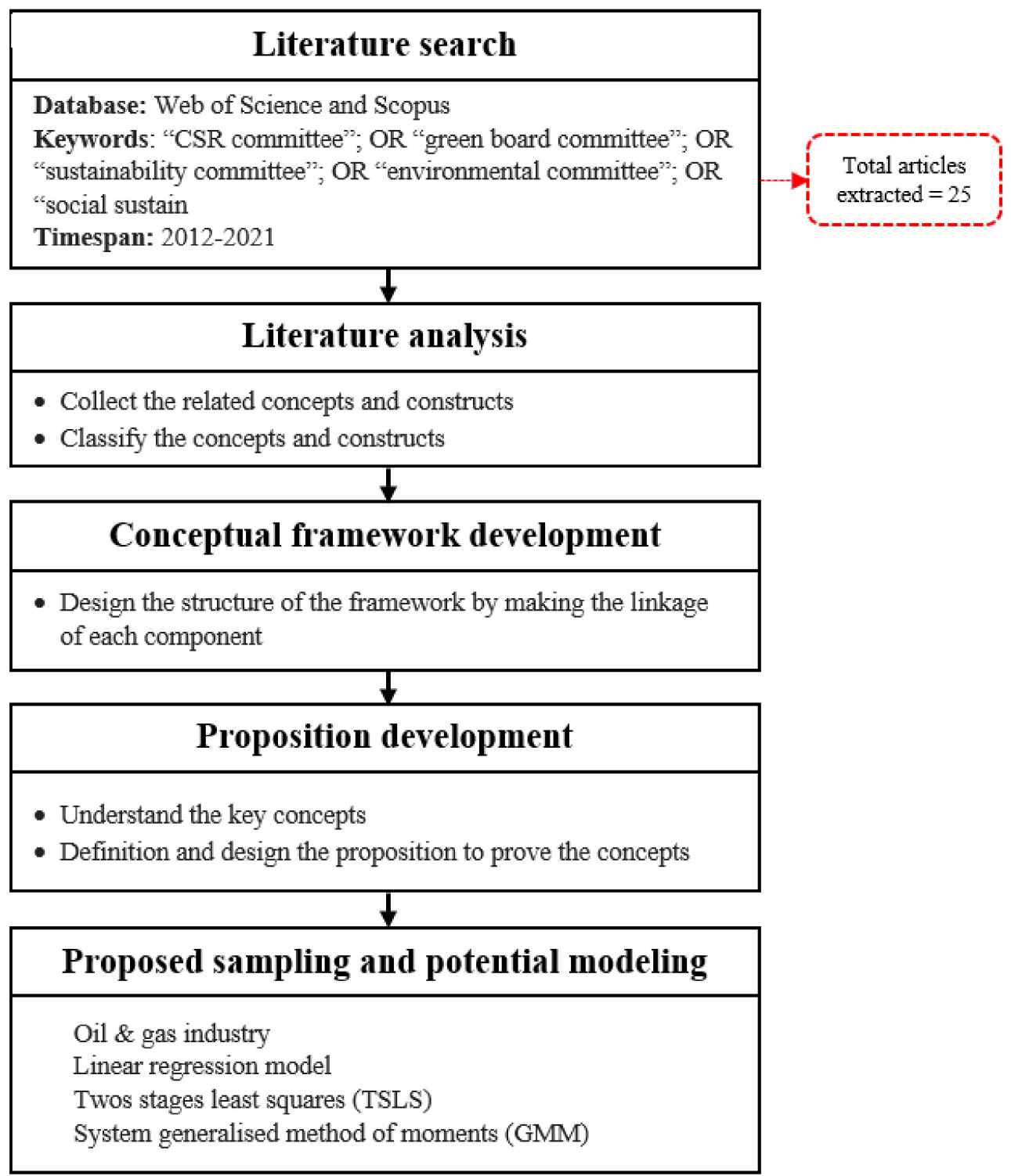

Figure 3. Graphical view of the study.

\section{Measurement of Variables}

\subsection{Development of the Green Board Committee Measurement Index}

This study attempted to propose a measurement index for green board committees. Several studies have used the green board committee as an independent variable to identify its impact on multiple dependent variables, such as environmental, social, and financial performance viz-a-viz sustainability reporting and many more [77]. It has been observed that green board committees are measured as a binary variable and marked with 1 if the organisation has a green board committee and 0 if otherwise. A novel contribution to the existing studies is introduced by proposing a green board committee index that includes practices performed by the green board committees. In light of the literature, the practices by the green board committee have been split into four major dimensions/parts, as shown in Table 2. Each dimension is discussed in the subsequent sections. 
Table 2. Summary of measurement of variables.

\begin{tabular}{ccc}
\hline Variables & Dimensions & \multicolumn{1}{c}{ Elements } \\
\cline { 2 - 3 } & Strategy and policy & $\begin{array}{c}\text { (a) Information on green board } \\
\text { committees' engagement in strategy } \\
\text { and policymaking of the firm }\end{array}$ \\
\cline { 2 - 3 } $\begin{array}{c}\text { Green board } \\
\text { committee } \\
\text { index }\end{array}$ & Risk management & $\begin{array}{c}\text { (b) Information on the green board } \\
\text { committees' engagement in monitoring } \\
\text { and control of the firm }\end{array}$ \\
\cline { 2 - 3 } & $\begin{array}{c}\text { Monitoring and } \\
\text { controlling }\end{array}$ & $\begin{array}{c}\text { (c) Information on green board } \\
\text { committees' engagement in the } \\
\text { sustainability reporting of the firm }\end{array}$ \\
\hline Intellectual capital & Sustainability reporting & $\begin{array}{c}\text { (d) Information on the green board } \\
\text { committees' engagement in the risk } \\
\text { management of the firm }\end{array}$ \\
\hline Firm performance & Shareholder value-added & Equation (3) \\
\hline
\end{tabular}

\subsubsection{Strategy and Policy}

Evidence from studies suggests that green board committees play an essential role in the strategy and policymaking of the companies [78]. Al-Shaer and Zaman [79] have argued that board committees provide insightful advice to management in strategies related to sustainability and stakeholder expectations. The green board committee assists the board of directors (BOD) in integrating social and environmental sustainability into business strategies [80]. It also contributes to the company-related policies regarding sustainability [3]. Such committees demonstrate sustainability-related strategies and policies [81]. They shape the missions and strategies to drive enterprises towards sustainability [44]. Such committees assist in management-related policymaking [41]. The BOD forms a green board committee for an advisory role on social and environmental issues [7], which are latterly considered in the organisation strategy and policymaking. From the above discussion, the following measuring element is assumed under the dimension of strategies and policies of the green board committee index, i.e.,

(a) Information on a green board committee's engagement in the strategy and policymaking of the firm.

\subsubsection{Monitoring and Control}

Klettner et al. [82] have provided an insight into green-board-committee monitoring and corporate strategy implementation. Due to our proclivity for opportunistic behaviour, managers can work for their self-interest. However, green board committees can closely monitor managers and align the firm's and the stakeholders' goals [33]. Such committees control the decision taken by the management related to the company's sustainability issues [44]. As mentioned before, being part of the corporate governance mechanism, these committees monitor sustainability and ensure organisational compliance with its policies [81]. Using the previously stipulated arguments, the following measuring element for the green board committee index is assumed under the dimension of monitoring and control, i.e.,

(b) Information on the green board committees' engagement in the monitoring and control of the firm.

\subsubsection{Sustainability Reporting}

In the present era of climate change, oil and gas companies around the globe are facing extreme pressure from stakeholders to disclose sustainability practices [33]. The curiosity of stakeholders in knowing the financial and non-financial information regarding such 
companies has increased remarkably. To diffuse stakeholder pressure, today, companies release their sustainability reports. In such a situation, green board committees play a vital role in inspecting the content of sustainability reporting. It conveys information to shareholders and stakeholders through sustainability reporting about how the company responds to sustainability issues. A study has argued that green board committees assist companies in non-financial reporting [28]. Similar research asserts the improvement of company performance through disclosure of sustainability reports [83]. In light of the above discussion, the following measuring element for the green board committee index is assumed under the dimension of sustainability reporting, i.e.,

(c) Information on the green board committees' engagement in the sustainability reporting of the firm.

\subsubsection{Risk Management}

As mentioned before, the green board committee plays an instrumental role in managing emerging risks [10]. A reputed report sheds light on forming a specific committee with the aim of monitoring, recognising, and evaluating environmental, social, and governance (ESG)-related risks [84]. It was agreed upon that companies might face financial risks other than ESG risks for which a green board committee communicates with other board committees, such as audit and risk committees. Such committees protect the firm value by overcoming sustainability risks [85]. It creates awareness as to how the emerging risks affect organisational competitive advantage and value. It provides mitigation actions to address the risks [39]. Such committees are beneficial for organisations because they provide an essential insight into risk management strategies and because they ensure the compliance of an enterprise with sustainability guidelines [13]. From the above evidence, the following measuring element for the green board committee index is assumed under the dimension of risk management, i.e.,

(d) Information on the green board committees' engagement in the risk management of the firm.

The green board committee index comprises four measuring elements, as depicted in Table 2. If complete information on each element was displayed in the annual reports, a value of 2 is placed. If the element was partially disclosed or completely absent in the annual reports, then a value of 1 or 0 was provided, respectively. Finally, the green board committee index value was calculated using the following formula.

$$
\text { Green board commitee index }=\frac{\sum \mathrm{X}}{\mathrm{N}}
$$

$\Sigma X$ represents the number of practices performed by the green board committee, and $\mathrm{N}$ represents the total number of practices.

\subsection{Dependent Variable}

Shareholder value-added (SVA), which is the excess amount of income that the firms earn after the deduction of funding cost, was taken as the dependent variable [51]. It is calculated as follows:

$$
\text { SVA }=\text { NOPAT }- \text { WACC }
$$

SVA stands for shareholder value-added. NOPAT is the net operating profit after tax, which is also known as the operational efficiency of the firm. The WACC is the weighted average cost of capital, including the cost of debt and equity.

\subsection{Moderating Variable}

The IC was used as the moderating variable. It was computed through a ratio [17], a content analysis [86], and a questionnaire [16]. The present study recommends a valueadded intellectual coefficient (VAIC) model invented by Pulic [87] for the computation of IC. The reason for choosing this technique was its simplicity and accuracy in terms of 
computation. This technique could identify the overall IC and its major components, such as human and structural capital. This technique is widely accepted by the UK's Department for Business, Innovation, and Skills [88], increasing its worthiness and strengthening its validity. VAIC can be computed as follows:

$$
\mathrm{VAIC}=\mathrm{CEE}+\mathrm{HCE}+\mathrm{SCE}
$$

In Equation (4), VAIC refers to the value-added intellectual coefficient, while CEE is the capital-employed efficiency, HCE is the human capital efficiency, and SCE is the structural capital efficiency. It is important to compute the total value (VA) created by the firm to calculate these variables. VA is computed as follows [89]:

$$
\mathrm{VA}=\mathrm{OP}+\mathrm{EC}+\mathrm{A} / \mathrm{D}
$$

where OP is operating profit, EC is employee cost, A is amortisation, and D is depreciation. VA was utilised to measure the components of VAIC (HCE, CEE, and SCE). CEE was calculated as follows:

$$
\mathrm{CEE}=\mathrm{VA} / \mathrm{CE}
$$

In Equation (6), VA is the total value created by the firm, and CE is capital employed, which is also known as the book value of assets. The components HCE and SCE were computed as:

$$
\begin{aligned}
& \mathrm{HCE}=\mathrm{VA} / \mathrm{HC} \\
& \mathrm{SC}=\mathrm{VA}-\mathrm{HC} \\
& \mathrm{SCE}=\mathrm{SC} / \mathrm{VA}
\end{aligned}
$$

In the Equations (6) and (8), $\mathrm{HC}$ is the personnel expenses of the firm, and SC is the difference between VA and $\mathrm{HC}$.

\section{Discussion}

Scant literature is available on the green board committees and their role in the performance of firms. The study [10] explored the little attention paid by researchers on green board committees and firm performance. A conceptual framework has not been observed for green board committees and firm financial value. This has drawn the attention of academics and practitioners to the importance of green board committees in firm performance.

The board of directors can produce sub-level committees to improve the firm performance. Green board committees were produced to focus on achieving sustainability and removing obstacles that stop an organisation from driving to sustainable developments. These committees perform multiple roles to meet the demands of stakeholders and shareholders. For instance, they engage in sustainability operations to ease stakeholders' concerns and to create a shared firm value. From the lens of stakeholder theory, green board committees contribute significantly to a firm's value by meeting the interests of diverse stakeholders via sustainability reporting. Thoroughly reviewing each content of non-financial reporting that comprises risk management reduces information asymmetry at every level of organisation and ultimately culminates in cost reduction and high firm performance. Through agency theory, the green board committee ensures that the management operations align with the company's mission, vision, and strategy. It helps hinder opportunistic behaviour at the managerial level and resolves the conflict of interests between principals and agents. Firms enjoy high profits in the absence of agency costs. Such committees bolster corporate governance and internal control through a supervision approach and through consideration of ESG issues. It assists in firm value creation by adopting a top-down approach to sustainability issues. Various researchers have investigated a positive correlation between green board committees and firm performance in the academic literature. This study assumed a significant positive impact between the two 
variables under the lens of the first two theories following the previous studies. The essence of IC is also highlighted in the study. A firm cannot last without IC investment. It increases the capacity and capability of an organisation at every level. IC provides a competitive advantage and increases the firm's value. Using RBV theory, the current study alludes to a positive moderating effect of IC on the relationship between green board committees and firm performance. Organisations with green board committees can preserve firm reputation and enjoy high shareholder value.

\section{Conclusions}

The study aimed to formulate a conceptual design that reflects on the practices of green board committees as it has an intertwined relationship with firm performance. A moderating role of IC on the nexus between two variables is suggested. The design paradigm will foster the understanding of corporations on the roles of green board committees towards the sustainable development of the firm. The study highlighted four major working areas in which the green board committee employed its expertise and knowledge: strategy and policymaking, monitoring and control, sustainability reporting, and risk management. This study hypothesised that firms could attain financial sustainability if their green board committee focused on the four aforementioned dimensions. An integration of IC with the green board committee might trigger the firm performance. The use of the proposed conceptual paradigm is not limited to the energy sector as the components are general, which can be applied to every type of industry. However, this study focused on the oil and gas sector due to its vulnerability in terms of sustainable risks. Such issues lead not only to economic losses but also to societal and ecological degradation. The existence of green board committees will assist a firm in performing cleaner sustainable operations and attaining financial sustainability. These committees would help reduce societal harm and might lead countries to low carbon emissions in the long run. It will help to achieve the sustainable development goals set by the United Nations. It is concluded that the conceptual framework and propositions might open new vistas of empirical validation and other moderating factors in the future.

This research claims the novelty of the conceptualisation of green board committees' practices and firm performance. Not many studies exist on the moderation of intellectual capital on such a paradigm. The execution of this study will foster the knowledge on firm performance with green governance in general and green board committees in particular. It contributes to the body of knowledge by employing the notion of agency and stakeholder theory to design an intertwined relationship between green board committees and firm performance. An empirical investigation of the proposed notion will uncover the important role of the green board committee in firm value.

The study provides a base for producing a green board committee index for firm performance. The literature shows that the green board committee is measured only as a binary variable. An index comprising four dimensions is produced. This contribution could provide a road map to future researchers and add other elements and dimensions in the proposed index to further enhance the proposed framework. Such a framework will work as a methodological base for the computation of firm value.

A green board committee is vital for the board and all stakeholders who have stakes in the firm. Its inclusion improves environmental and social performance, which positively affects an organisation's accounting performance. Based on the results, investors are encouraged to ask enterprises to produce green committees in the board room to face lower environmental and social risks and to enjoy high transparency in sustainability reports. The formation of these committees is also vital for aligning the interest between stakeholders and firms and may pursue the United Nation's sustainability goals. To avoid the significant financial, human, social, and ecological losses evident by the major Deepwater Horizon oil spill, firms have to employ green board committees to integrate risk management policies in the firm's sustainability. Policymakers may endorse the green board committees to ensure transparent disclosure of sustainability practices and implementation of CSR policies. 
The study provides information to managers and practitioners on achieving financial and non-financial benefits. It suggests to regulatory bodies that green board committees' existence mitigates the agency cost through monitoring and controlling, which, in turn, creates shareholder/stakeholder value by transparent sustainability reporting. Firms can sustain their value if green board committees emphasise stakeholders by forging a strong relationship with them.

Despite providing a high-scale contribution and policy implications, the study was confined to conceptualisation. It lacked empirical investigations. Therefore, future researchers are encouraged to empirically validate the paradigm. Researchers are encouraged to testify the designed framework in different countries with variant sample sizes in different industries. Future studies are invited to identify other moderating factors that can accelerate the nexus between green board committees and firm performance.

Author Contributions: Conceptualisation, S.Q.A.S. and F.-W.L.; methodology, Z.K., F.A.G. and A.G.C.; validation, Z.K., F.A.G. and A.G.C.; formal analysis, Z.K., F.A.G. and A.G.C.; investigation, Z.K., F.A.G. and A.G.C.; resources, J.J.K.; data curation, F.A.G. and A.G.C.; writing-original draft preparation, S.Q.A.S.; writing-review and editing, M.K.S.; visualisation, S.Q.A.S. and M.K.S.; supervision, F.-W.L. and J.J.K.; project administration, F.-W.L. and J.J.K.; funding acquisition, J.J.K. All authors have read and agreed to the published version of the manuscript.

Funding: This research was funded by the EU project "Sustainable Process Integration LaboratorySPIL", project No. CZ.02.1.01/0.0/0.0/15_003/0000456 funded by EU “CZ Operational Programme Research, Development and Education," Priority 1: strengthening capacity for quality research.

Institutional Review Board Statement: Not applicable.

Informed Consent Statement: Not applicable.

Data Availability Statement: The study did not report any data.

Acknowledgments: The researchers would like to acknowledge Yayasan Universiti Teknologi PETRONAS (YUTP) for funding this research grant under Cost Center: 015LCO-188, Management and Humanities Department, Center of Social Innovation (CoSI), Universiti Teknologi PETRONAS, which was an important support to conduct this research. Two authors in this study have been supported by the EU project "Sustainable Process Integration Laboratory-SPIL", project No. CZ.02.1.01/ 0.0/0.0/15_003/0000456 funded by EU “CZ Operational Programme Research, Development and Education", Priority 1: strengthening capacity for quality research.

Conflicts of Interest: The authors declare no conflict of interest.

\section{References}

1. Jan, A.A.; Lai, F.W.; Tahir, M. Developing an Islamic Corporate Governance framework to examine sustainability performance in Islamic Banks and Financial Institutions. J. Clean. Prod. 2021, 315, 128099. [CrossRef]

2. Tang, M.; Walsh, G.; Lerner, D.; Fitza, M.A.; Li, Q. Green innovation, managerial concern and firm performance: An empirical study. Bus. Strateg. Environ. 2018, 27, 39-51. [CrossRef]

3. Liao, L.; Luo, L.; Tang, Q. Gender diversity, board independence, environmental committee and greenhouse gas disclosure. Br. Account. Rev. 2015, 47, 409-424. [CrossRef]

4. Kilic, M.; Uyar, A.; Kuzey, C.; Karaman, A.S. Drivers and consequences of sustainability committee existence? Evidence from the hospitality and tourism industry. Int. J. Hosp. Manag. 2021, 92, 102753. [CrossRef]

5. Huang, H.; Lobo, G.J.; Zhou, J. Determinants and accounting consequences of forming a governance committee: Evidence from the United States. Corp. Gov. Int. Rev. 2009, 17, 710-727. [CrossRef]

6. Harrison, J.R. The strategic use of corporate board committees. Calif. Manag. Rev. 1987, 30, 109-125. [CrossRef]

7. García-Sánchez, I.M.; Gomez-Miranda, M.E.; David, F.; Rodríguez-Ariza, L. The explanatory effect of CSR committee and assurance services on the adoption of the IFC performance standards, as a means of enhancing corporate transparency. Sustain. Account. Manag. Policy J. 2019, 10, 773-797. [CrossRef]

8. Eberhardt-Toth, E. Who should be on a board corporate social responsibility committee? J. Clean. Prod. 2017, 140, 1926-1935. [CrossRef]

9. Gennari, F.; Salvioni, D.M. CSR committees on boards: The impact of the external country level factors. J. Manag. Gov. 2019, 23, 759-785. [CrossRef]

10. Burke, J.J.; Hoitash, R.; Hoitash, U. The Heterogeneity of Board-Level Sustainability Committees and Corporate Social Performance. J. Bus. Ethics 2019, 154, 1161-1186. [CrossRef] 
11. Mahmood, M.; Orazalin, N. Green governance and sustainability reporting in Kazakhstan's oil, gas, and mining sector: Evidence from a former USSR emerging economy. J. Clean. Prod. 2017, 164, 389-397. [CrossRef]

12. Antounian, C.; Dah, M.A.; Harakeh, M. Excessive managerial entrenchment, corporate governance, and firm performance. Res. Int. Bus. Financ. 2021, 56, 101392. [CrossRef]

13. Biswas, P.K.; Mansi, M.; Pandey, R. Board composition, sustainability committee and corporate social and environmental performance in Australia. Pac. Account. Rev. 2018, 30, 517-540. [CrossRef]

14. Salin, A.S.; Rahman, R.A. Disclosure of board committees by Malaysian public listed companies. In Proceedings of the International Conference on Economics, Business and Management, Manila, Philippines, 14-15 June 2010.

15. Saeidi, P.; Saeidi, S.P.; Gutierrez, L.; Streimikiene, D.; Alrasheedi, M.; Saeidi, S.P.; Mardani, A. The influence of enterprise risk management on firm performance with the moderating effect of intellectual capital dimensions. Econ. Res.-Ekon. Istraz. 2020, 34, 122-151. [CrossRef]

16. Bontis, N.; Ciambotti, M.; Palazzi, F.; Sgro, F. Intellectual capital and financial performance in social cooperative enterprises. J. Intellect. Cap. 2018, 19, 712-731. [CrossRef]

17. Ozkan, N.; Cakan, S.; Kayacan, M. Intellectual capital and financial performance: A study of the Turkish Banking Sector. Borsa Istanb. Rev. 2017, 17, 190-198. [CrossRef]

18. Dal Mas, F. The relationship between intellectual capital and sustainability: An analysis of practitioner's thought. In Intellectual Capital Management as a Driver of Sustainability: Perspectives for Organisations and Society; Matos, F., Vairinhos, V., Maurício Selig, P., Edvinsson, L., Eds.; Springer: Cham, Switzerland, 2019; pp. 11-24.

19. Shad, M.K.; Lai, F.W.; Shamim, A.; McShane, M. The efficacy of sustainability reporting towards cost of debt and equity reduction. Environ. Sci. Pollut. Res. Int. 2020, 27, 22511-22522. [CrossRef]

20. Elsayed, N.; Ammar, S. Sustainability governance and legitimisation processes: Gulf of Mexico oil spill. Sustain. Account. Manag. Policy J. 2020, 11, 253-278. [CrossRef]

21. Baalouch, F.; Ayadi, S.D.; Hussainey, K. A study of the determinants of environmental disclosure quality: Evidence from French listed companies. J. Manag. Gov. 2019, 23, 939-971. [CrossRef]

22. Chen, F.; Ngniatedema, T.; Li, S. A cross-country comparison of green initiatives, green performance and financial performance. Manag. Decis. 2018, 56, 1008-1032. [CrossRef]

23. Dangelico, R.M. Improving firm environmental performance and reputation: The role of employee green teams. Bus Strateg. Environ. 2015, 24, 735-749. [CrossRef]

24. Uyar, A.; Kilic, M.; Koseoglu, M.A.; Kuzey, C.; Karaman, A.S. The link among board characteristics, corporate social responsibility performance, and financial performance: Evidence from the hospitality and tourism industry. Tour. Manag. Perspect. 2020, 35, 100714. [CrossRef]

25. Li, S.; Ngniatedema, T.; Chen, F. Understanding the impact of green initiatives and green performance on financial performance in the US. Bus. Strateg. Environ. 2017, 26, 776-790. [CrossRef]

26. Li, W.; Xu, J.; Zheng, M. Green governance: New perspective from open innovation. Sustainability 2018, 10, 3845. [CrossRef]

27. Ienciu, I.-A.; Popa, I.E.; Ienciu, N.M. Environmental reporting and good practice of corporate governance: Petroleum industry case study. Procedia Econ. Financ. 2012, 3, 961-967. [CrossRef]

28. Walls, J.L.; Berrone, P.; Phan, P.H. Corporate governance and environmental performance: Is there really a link? Strateg. Manag. J. 2012, 33, 885-913. [CrossRef]

29. Michelon, G.; Parbonetti, A. The effect of corporate governance on sustainability disclosure. J. Manag. Gov. 2012, 16, 477-509. [CrossRef]

30. Rupley, K.H.; Brown, D.; Marshall, R.S. Governance, media and the quality of environmental disclosure. J. Account. Public Policy 2012, 31, 610-640. [CrossRef]

31. Rodrigue, M.; Magnan, M.; Cho, C.H. Is environmental governance substantive or symbolic? An empirical investigation. J. Bus. Ethics 2013, 114, 107-129. [CrossRef]

32. Vigneau, L.; Humphreys, M.; Moon, J. How Do Firms Comply with International Sustainability Standards? Processes and Consequences of Adopting the Global Reporting Initiative. J. Bus. Ethics 2015, 131, 469-486. [CrossRef]

33. Hussain, N.; Rigoni, U.; Orij, R.P. Corporate governance and sustainability performance: Analysis of triple bottom line performance. J. Bus. Ethics 2018, 149, 411-432. [CrossRef]

34. Mahmood, Z.; Kouser, R.; Ali, W.; Ahmad, Z.; Salman, T. Does corporate governance affect sustainability disclosure? A mixed methods study. Sustainability 2018, 10, 207. [CrossRef]

35. Adel, C.; Hussain, M.M.; Mohamed, E.K.; Basuony, M.A. Is corporate governance relevant to the quality of corporate social responsibility disclosure in large European companies? Int. J. Account. Inf. Manag. 2019, 27, 301-332. [CrossRef]

36. Cancela, B.L.; Neves, M.E.D.; Rodrigues, L.L.; Dias, A.C.G. The influence of corporate governance on corporate sustainability: New evidence using panel data in the Iberian macroeconomic environment. Int. J. Account. Inf. Manag. 2020, 28, 785-806. [CrossRef]

37. Orazalin, N. Do board sustainability committees contribute to corporate environmental and social performance? The mediating role of corporate social responsibility strategy. Bus. Strategy Environ. 2020, 29, 140-153. [CrossRef]

38. Noja, G.G.; Cristea, M.; Jurcut, C.N.; Buglea, A.; Lala Popa, I. Management financial incentives and firm performance in a sustainable development framework: Empirical evidence from European companies. Sustainability 2020, 12, 7247. [CrossRef] 
39. Shahbaz, M.; Karaman, A.S.; Kilic, M.; Uyar, A. Board attributes, CSR engagement, and corporate performance: What is the nexus in the energy sector? Energy Policy 2020, 143, 111582. [CrossRef]

40. Elmaghrabi, M.E. CSR committee attributes and CSR performance: UK evidence. Corp. Gov. 2021, 21, 892-919. [CrossRef]

41. Eccles, R.G.; Ioannou, I.; Serafeim, G. The impact of corporate sustainability on organisational processes and performance. Manag. Sci. 2014, 60, 2835-2857. [CrossRef]

42. Calvert Asset Management and the Corporate Library. Board Oversight of Environmental and Social Issues: An Analysis of Current North American Practice. 2010. Available online: http:/ / plusweb.org/Portals/0/DandO\%20Material\%202011/Board\% 20Oversight\%20of\%20Env\%20\&\%20Social\%20Issues.pdf (accessed on 28 June 2021).

43. Institute of Business Ethics. Culture by Committee: The Pros and Cons; Institute of Business Ethics Pub: London, UK, 2016.

44. Cucari, N.; De Falco, E.S.; Orlando, B. Diversity of board of directors and environmental social governance: Evidence from Italian listed companies. Corp. Soc. Responsib. Environ. Manag. 2017, 25, 250-266. [CrossRef]

45. Richard, P.J.; Devinney, T.M.; Yip, G.S.; Johnson, G. Measuring organisational performance: Towards methodological best practice. J. Manag. 2009, 35, 718-804.

46. Chakravarthy, B.S. Measuring strategic performance. Strateg. Manag. J. 1986, 7, 437-458. [CrossRef]

47. Kaplan, R.S.; Norton, D.P. The Balanced Scorecard: Translating Strategy into Action; Harvard Business School Press: Boston, MA, USA, 1996.

48. Shad, M.K.; Lai, F.W.; Fatt, C.L.; Klemeš, J.J.; Bokhari, A. Integrating sustainability reporting into enterprise risk management and its relationship with business performance: A conceptual framework. J. Clean. Prod. 2019, 208, 415-425. [CrossRef]

49. Fernandez, P. EVA, economic profit and cash value added do not measure shareholder value creation. Fecha De Publicación 2001, $22,1-18$.

50. Fernández, P. A Definition of Shareholder Value Creation. Master's Thesis, IESE Business School, University of Navarra, Pamplona, Spain, 2002.

51. Largani, M.S.; Kaviani, M.; Abdollahpour, A. A review of the application of the concept of Shareholder Value Added (SVA) in financial decisions. Procedia Soc. Behav. Sci. 2012, 40, 490-497. [CrossRef]

52. Rappaport, A. Creating Shareholder Value: The New Standard for Business Performance; Free Press: New York, NY, USA, 1986.

53. Jensen, M.C.; Meckling, W.H. Theory of the firm: Managerial behavior, agency costs and ownership structure. J. Financ. Econ. 1976, 3, 305-360. [CrossRef]

54. Laplume, A.O.; Sonpar, K.; Litz, R.A. Stakeholder theory: Reviewing a theory that moves us. J. Manag. 2008, 34, 1152-1189. [CrossRef]

55. Aras, G.; Tezcan, N.; Kutlu Furtuna, O. Multidimensional comprehensive corporate sustainability performance evaluation model: Evidence from an emerging market banking sector. J. Clean. Prod. 2018, 185, 600-609. [CrossRef]

56. Khan, P.A.; Johl, S.K.; Johl, S.K. Does adoption of ISO 56002-2019 and green innovation reporting enhance the firm sustainable development goal performance? An emerging paradigm. Bus. Strateg. Environ. 2021, 1-15. [CrossRef]

57. Donaldson, T.; Preston, L.E. The Stakeholder Theory of the Corporation: Concepts, Evidence, and Implications. Acad. Manag. Rev. 1995, 20, 65-91. [CrossRef]

58. Peteraf, M.A. The cornerstones of competitive advantage: A resource-based view. Strateg. Manag. J. 1993, 14, 179-191. [CrossRef]

59. Barney, J. Firm Resources and Sustained Competitive Advantage. J. Manag. 1991, 17, 99-120. [CrossRef]

60. Chofreh, A.G.; Goni, F.A.; Shaharoun, A.M.; Ismail, S. Review on enterprise resource planning implementation roadmap: Project management perspective. Sains Hum. 2014, 2, 135-138.

61. Nadeem, M.; Gan, C.; Nguyen, C. The importance of intellectual capital for firm performance: Evidence from Australia. Aust. Account. Rev. 2018, 28, 334-344. [CrossRef]

62. Camilleri, M. Valuing Stakeholder Engagement and Sustainability Reporting. Corp. Reput. Rev. 2015, 18, 210-222. [CrossRef]

63. Pranugrahaning, A.; Donovan, J.D.; Topple, C.; Masli, E.K. Corporate Sustainability Assessments: A systematic literature review and conceptual framework. J. Clean. Prod. 2021, 295, 126385. [CrossRef]

64. Baron, R.M.; Kenny, D.A. The moderator-mediator variable distinction in social psychological research: Conceptual, strategic, and statistical considerations. J. Pers. Soc. Psychol. 1986, 51, 9. [CrossRef]

65. Chofreh, A.G.; Goni, F.A.; Klemeš, J.J.; Moosavi, S.M.S.; Davoudi, M.; Zeinalnezhad, M. COVID-19 shock: Development of strategic management framework for global energy. Renew. Sustain. Energy Rev. 2020, 139, 110643. [CrossRef]

66. Ali, M.; de Azevedo, A.R.; Marvila, M.T.; Khan, M.I.; Memon, A.M.; Masood, F.; Almahbashi, N.M.; Shad, M.K.; Khan, M.A.; Fediuk, R.; et al. The Influence of COVID-19-Induced Daily Activities on Health Parameters-A Case Study in Malaysia. Sustainability 2021, 13, 7465. [CrossRef]

67. Izzo, F.; Tomnyuk, V.; Varavallo, G. Intellectual capital and company performance: Evidence from European FinTech companies. Int. Bus. Res. 2020, 13, 1-34. [CrossRef]

68. Tahir, M.; Shah, S.Q.A.; Khan, M.M.; Afridi, M.A. Intellectual Capital and Financial Performance of Banks in Pakistan. Dialogue 2018, 13, 105-117.

69. Gangi, F.; Salerno, D.; Meles, A.; Daniele, L.M. Do corporate social responsibility and corporate governance influence intellectual capital efficiency? Sustainability 2019, 11, 1899. [CrossRef]

70. Frederickson, J.R.; Webster, E.; Williamson, I.O. Is the current accounting treatment of education and training costs appropriate? Aust. Account. Rev. 2010, 20, 265-273. [CrossRef] 
71. Massaro, M.; Dumay, J.; Garlatti, A.; Dal Mas, F. Practitioners' views on intellectual capital and sustainability. J. Intellect. Cap. 2018, 19, 367-386. [CrossRef]

72. Vaio, A.D.; Palladino, R.; Hassan, R.; Escobar, O. Artificial intelligence and business models in the sustainable development goals perspective: A systematic literature review. J. Bus. Res. 2020, 121, 283-314. [CrossRef]

73. Ali, S.E.A.; Lai, F.W.; Dominic, P.D.D.; Brown, N.J.; Lowry, P.B.B.; Ali, R.F. Stock Market Reactions to Favorable and Unfavorable Information Security Events: A Systematic Literature Review. Comput. Secur. 2021, 110, 102451. [CrossRef]

74. Jan, A.; Marimuthu, M.; bin Mohd, M.P.; Isa, M.; Shad, M.K. Bankruptcy forecasting and economic sustainability profile of the market leading islamic banking countries. Int. J. Asian Bus. Inf. Manag. 2019, 10, 73-90. [CrossRef]

75. Hamad, S.; Draz, M.U.; Lai, F.W. The Impact of Corporate Governance and Sustainability Reporting on Integrated Reporting: A Conceptual Framework. SAGE Open. 2020, 10, 2158244020927431. [CrossRef]

76. Tahir, M.; Jan, A.A.; Shah, S.Q.A.; Alam, M.B.; Afridi, M.A.; Tariq, Y.B.; Bashir, M.F. Foreign inflows and economic growth in Pakistan: Some new insights. J. Chin. Econ. Foreign Trade Stud. 2020, 13, 97-113. [CrossRef]

77. Jabbour, C.J.C.; Santos, F.C.A.; Fonseca, S.A.; Nagano, M.S. Green teams: Understanding their roles in the environmental management of companies located in Brazil. J. Clean. Prod. 2013, 46, 58-66. [CrossRef]

78. Lun, Y.H.V. Green management practices and firm performance: A case of container terminal operations. Resour. Conserv. Recycl. 2011, 55, 559-566. [CrossRef]

79. Al-Shaer, H.; Zaman, M. Credibility of sustainability reports: The contribution of audit committees. Bus. Strateg. Environ. 2018, 27, 973-986. [CrossRef]

80. Marlow, D.; Beale, D.; Burn, S. Linking asset management with sustainability: Views from the Australian sector. J. Am. Water Work. Ass. 2010, 102, 56-67. [CrossRef]

81. Jorge, I.C. The Influence of the CSR Committee in Firms' Financial and Non-Financial Performance: Evidence from France, Germany, and the U.K. Master's Thesis, ISCTE-Lisbon University Institute, Lisbon, Portugal, 2020.

82. Klettner, A.; Clarke, T.; Boersma, M. The governance of corporate sustainability: Empirical insights into the development, leadership and implementation of responsible business strategy. J. Bus. Ethics 2014, 122, 145-165. [CrossRef]

83. Spitzeck, H. The development of governance structures for corporate responsibility. Corp. Gov. Int. J. Bus. Soc. 2009, 9, 495-505. [CrossRef]

84. COSO; WBCSD. Enterprise Risk Management: Applying Enterprise Risk Management to Environmental, Social and GovernanceRelated Risks. Available online: https:/ / www.coso.org/Documents/COSO-WBCSD-ESGERM-Guidance-Full.pdf (accessed on 21 January 2021).

85. Cordeiro, J.J.; Profumo, G.; Tutore, I. Board gender diversity and corporate environmental performance: The moderating role of family and dual-class majority ownership structures. Bus. Strategy Environ. 2020, 29, 1127-1144. [CrossRef]

86. Dumay, J. A critical reflection on the future of intellectual capital: From reporting to disclosure. J. Intellect. Cap. 2016, 17, 168-184. [CrossRef]

87. Pulic, A. Measuring the performance of intellectual potential in knowledge economy. In 2nd McMaster Word Congress on Measuring and Managing Intellectual Capital by the Austrian Team for Intellectual Potential; McMaster University: Hamilton, ON, Canada, 1998.

88. Singla, H.K. Does VAIC affect the profitability and value of real estate and infrastructure firms in India? A panel data investigation. J. Intellect. Cap. 2020, 21, 309-331. [CrossRef]

89. Pulic, A. Intellectual capital-Does it create or destroy value? Meas. Bus. Excell. 2004, 8, 62-68. [CrossRef] 